\title{
What Impact Does Innovation and Sustainable Entrepreneurship Have on Competitiveness?
}

\author{
Cristina Isabel I. Fernandes, University of Beira Interior, Covilhã, Portugal \\ Pedro Mota Veiga, Universidade Portucalense, Porto, Portugal \\ Marta Peris-Ortiz, Universitat Politècnica de València, Valencia, Spain \\ Carlos Rueda-Armengot, Universitat Politècnica de València, Valencia, Spain
}

\begin{abstract}
Sustainable development and entrepreneurship are increasingly high profile issues and matters of importance to different international agendas. Alongside this interest, there have emerged studies on entrepreneurship and innovation that point to their driving positive impacts at the level of regional development. With their research the authors intend to bridge the gap that exists in the literature on the relationship between innovation and sustainable entrepreneurship, in the sense that innovation does not have to imply actions that suppose a growth of entrepreneurship without any planning. The objectives of this research involve contributing towards the literature on this field of study in terms of knowledge about which environmental and innovation variables best foster the greatest impact of entrepreneurial activities. To this end, the authors deployed aggregate data at the national level gathered by the Environment, Population, International Trade, Labour and National Accounts Statistics, from the Organization for Economic Cooperation and Development (OECD) for the years between and including 2005 and 2012 and for the 35 member states of this organisation. They correspondingly verify that environmental patents do have a positive impact on Real GDP.
\end{abstract}

\section{KEYWORDS}

Entrepreneurship, Environmental Patents, OECD, Regional Development

\section{INTRODUCTION}

Entrepreneurial activities, as well as all of the factors underpinning their existence, and their influence on regional economic development, have all been the subject of study by various different authors (Birley 1985, Kirchoff and Phillips 1988; Storey, 1994, Lafuente, 2010; Ferreira et al. 2016). Similarly, the question of regional development has awoken the interest of a diverse range of national and international researchers (Cooke, 2002; Farinha et al, 2014). Entrepreneurship correspondingly seems to have emerged as a factor contributing to regional development (Parrish, 2010). In terms of the relationship between entrepreneurship and economic growth, Wennekers and Thurik (1999) conclude that understanding how entrepreneurship takes place is an essential factor for economic growth. The NCOE (National Commission on Entrepreneurship) White Paper (2001) maintains that the greatest contribution made by entrepreneurship at the local level stems from its innovation. Thus, innovation combined with entrepreneurship drives the following benefits at the local level: 
1) quality of life; 2) generating new employment; 3) fostering economic competitiveness; and 4) boosting economic growth and wealth. Acs and Varga (2005) developed their research based upon two relationships: geography and technology, and entrepreneurship and technology with the argument that these relationships are fundamental to any explanation of economic development. They conclude that the effects of agglomeration on technological change, or should we prefer, on innovation, are positive and statistically significant. The interest of our research encapsulates contributing to the literature on this field of study approaching just how environment and innovation variables foster a greater impact on entrepreneurial activities. To this end, we applied aggregate data at the national level gathered by thee Environment, Population, International Trade, Labour and National Accounts Statistics, by the Organization for Economic Cooperation and Development (OECD) between 2005 and 2012 for its 35 member states. Our research findings convey how total patent numbers hold a statistically significant effect on Real GDP growth. As regards the three types of environmental patents, we may report that environmental management patents and environmental patents hold a statistically significant positive effect on Real GDP growth.

\section{THEORETICAL BACKGROUND}

According to Schumpeter (1934), business owners/entrepreneurs are individuals undertaking the function of deploying new combinations of resources and the entrepreneurial role consists of identifying and leveraging new opportunities in the economy. The recent interest in the role played by entrepreneurship in economic development was to a large extent shaped by the revolution in endogenous growth, at the global level, in the mid-1980s. This revolution resulted in a new wave of research centred upon the "individual capacity to confront risk" at the core of their economic analyses (Groot et al., 2004, Ferreira et al. 2016). However, interest in the role of entrepreneurs and their activities predates this period. A long time ago, Schumpeter $(1934,1939,1942)$ defended that entrepreneurs represented the driving strength powering economic development. Indeed, he deemed they were able to foster the innovations that would enable them to obtain profits while assuming the risks inherent to such "creations." According to this author, development means the introduction of new combinations of circular flows into economic life, hence, the entrepreneur proves able to introduce innovative actions to such an extent that these trigger cyclical discontinuities in the economic cycles. Such combinations then get put into practice by these new actors, the business owners. They develop new means of production, new products, new technologies, new forms of organisation, new markets and new resources for their productions, thus shaping the very progress of economic development and the future of capitalism.

Furthermore, interest in entrepreneurship related matters has also emerged among governments. Correspondingly, entrepreneurship as a mechanism for qualified economic development, able to guarantee the provision of goods and services to the community whilst also generating employment and the consequent wealth, ensures that governments have designed policies tailored to support such phenomena (Audretsch and Fritsch, 2002). Therefore, the host territory and its companies and firms mutually interrelate given that the latter contribute towards territorial development while this same territory simultaneously provides an environment favourable or otherwise to their existence and operations. According to Global Entrepreneurship Monitor (GEM, 2014), entrepreneurship related phenomena are, above all else, complex in nature. The variety of interrelated concepts proves both extremely broad and high in number. Even before a company begins operations, the entrepreneurial process has already long since got underway. Here, we should also stress how there are also two types of entrepreneurs: individuals who simply seek to embark on a business adventure and attempt to do 
so in competitive markets despite not having major aspirations over rates of growth; or, alternatively, they may be individuals who have a given business for a specific period of years and in this period of time set about its innovation. This individual is an entrepreneur.

This research therefore state that entrepreneurship and innovation are central aspects to creative economic processes as well as serving to foster knowledge, boost productivity and bring about employment opportunities. Thus, the competitiveness of any region stems from a dynamic process with the levels of development shaped by the interactions ongoing between the currently prevailing situations in market and the return on investment in innovation. Investments in R\&D help shift the lines of growth for companies in keeping with their capacity to drive the creation of new products, new processes and the new organisational methods that prove able to alter the compositions of markets (Fernandes and Ferreira, 2013). Furthermore, according to Drucker (1985), innovation is a specific instrument of entrepreneurs. This is an act that endows new capacities and means of generating wealth. In fact, innovation returns a resource. There are effectively no "resources" until man discovers them in nature and proves able to render economic value from them. Innovation constitutes the process by which opportunities get transformed into practice utility (Tidd et al, 1997). The effective implementation of innovation has increasingly been recognised as a synonym for the building up of sustained competitive advantage and therefore strengthening the overall performance of organisations (Koc and Ceylan, 2007). In an increasingly competitive environment, innovation is a critical factor so that these companies prove able to achieve dominant positions and as well as raising their profit levels (Hu and Hsu, 2008; Kaminski et al., 2008). There are various authors who defend how innovation would seem to be the only route enabling companies to survive and adapt in increasingly dynamic environments (Roberts and Amit, 2003; Hua and Wmmerlov, 2006; Doloreux and Melancon, 2008). Through the analysis of the introduction of new processes, products and ideas at the organisational level, it is possible to measure the innovative capacities of companies (Hurley and Hult, 1998). Innovation, nevertheless, arises from the flexibility of companies in selecting different options able to meet the desires and wishes of their consumers (Banbury and Mitchell, 1995) through a sustained strategy focused on company resources and capacities, which enables not only the meeting of those demands but also doing so into the future (Wernerfelt, 1984; Barney, 1991; Drazin and Schoonhoven, 1996; Tushman and O'Reilly, 1997; Souitaris, 2002; Hwang, 2004; Lemon and Sahota, 2004).

\section{METHODOLOGY}

\subsection{Data}

The data applied incorporates the aggregate data collected at the national level by the Environment, Population, International Trade, Labour and National Accounts Statistics from the Organization for Economic Cooperation and Development (OECD) for the years between and including 2005 and 2012 and for its 35 member states. Table 1 lists the 35 countries included in the study. The chosen databases and the variables used are those that we consider to be the most adequate for the investigation that we intend to do. Also based on other investigations that use similar variables.

\subsection{Measures}

\subsubsection{Dependent Variable}

The dependent variable applied in this study is real GDP growth (Annual growth in percentage).

\subsubsection{Predictor Variables}

\subsubsection{Control Variables}


Table 1. Countries

\begin{tabular}{|l|l|}
\hline Australia & Korea \\
\hline Austria & Latvia \\
\hline Belgium & Luxembourg \\
\hline Canada & Mexico \\
\hline Chile & Netherlands \\
\hline Czech Republic & New Zealand \\
\hline Denmark & Norway \\
\hline Estonia & Poland \\
\hline Finland & Portugal \\
\hline France & Slovak Republic \\
\hline Germany & Slovenia \\
\hline Greece & Spain \\
\hline Hungary & Sweden \\
\hline Iceland & Switzerland \\
\hline Ireland & Turkey \\
\hline Israel & United Kingdom \\
\hline Italy & United States \\
\hline Japan & \\
\hline
\end{tabular}

The control variables applied stem from the population growth rates (annual growth in percentage), gross fixed capital formation (annual growth in percentage), current account balance (as a percentage of GDP) and average hours actually worked (annual per employee in thousands).

\subsubsection{Patent Variables}

In relation to the variables for patents, we applied all technology patents (number per million of inhabitants), and environment-related technology patents (number per million of inhabitants), with

Table 2. Analysis variables

\begin{tabular}{|l|l|}
\hline \multicolumn{1}{|c|}{ Variable } & \multicolumn{1}{c|}{ Units } \\
\hline Real GDP growth (GDP_GR) & Annual growth in percentage \\
\hline Population growth rates (POP_GR) & Annual growth in percentage \\
\hline Gross fixed capital formation (GFC) & Annual growth in percentage \\
\hline Current account balance (CAB) & As a percentage of GDP \\
\hline Average annual hours actually worked per worker (HOUR) & Annual by employee in thousands \\
\hline All technologies patents (PAT) & Per million of inhabitants \\
\hline Selected environment-related technologies patents (PAT_ENV) & Per million of inhabitants \\
\hline Environmental management patents (PAT_ENV_MAN) & Per million of inhabitants \\
\hline Water-related adaptation technologies patents (PAT_ENV_WAT) & Per million of inhabitants \\
\hline Climate change mitigation patents (PAT_ENV_CLIM) & Per million of inhabitants \\
\hline
\end{tabular}


the latter breaking down into environmental management patents (number per million of inhabitants), water-related adaptation technology patents (number per million of inhabitants), and climate change mitigation patents (number per million of inhabitants).

Table 2 sets out a summary of the range of variables applied in this study.

\subsection{Data Analysis}

The econometric analysis applied to evaluate the influence of patents, in particular those interconnected with environmental matters and GDP growth, was structured by panel based regression models. The data corresponded to a balanced panel given that the set of 35 countries did not provide values for all variables for all eight years under analysis. In all cases, we estimated models with random effects through the Generalized Least Squares methodology.

Correspondingly, we calculated the following econometric models for each country:

1. $G D P P_{-} G R=\alpha_{0}+\alpha_{1} P O P \_G R+\alpha_{2} G F C+\alpha_{3} C A B+\alpha_{4} H O U R+\alpha_{5} P A T$

2. $G D P \_G R=\alpha_{0}+\alpha_{1} P O P \_G R+\alpha_{2} G F C+\alpha_{3} C A B+\alpha_{4} H O U R+\alpha_{5} P A T \times(E A=1)$

3. $G D P P_{-} G R=\alpha_{0}+\alpha_{1} P O P \_G R+\alpha_{2} G F C+\alpha_{3} C A B+\alpha_{4} H O U R+\alpha_{5} P A T \_E N V$

4.

$G D P P_{-} G R=\alpha_{0}+\alpha_{1} P O P{ }_{-} G R+\alpha_{2} G F C+\alpha_{3} C A B+\alpha_{4} H O U R+\alpha_{5} P A T \_E N V \times(E A=1)$

5. $G D P_{-} G R=\alpha_{0}+\alpha_{1} P O P \_G R+\alpha_{2} G F C+\alpha_{3} C A B+\alpha_{4} H O U R+$ $\alpha_{6} P A T_{-} E N V_{-} M A N+\alpha_{7} P A T_{-} E N V_{-} W A T+\alpha_{8} P A T_{-} E N V_{-} C L I M$ $G D P P_{-} G R=\alpha_{0}+\alpha_{1} P O P \_G R+\alpha_{2} G F C+\alpha_{3} C A B+\alpha_{4} H O U R+$

6. $\quad \alpha_{6} P A T_{-} E N V_{-} M A N \times(E A=1)+\alpha_{7} P A T_{-} E N V_{-} W A T \times(E A=1)+$ $\alpha_{8} P A T T_{-} E N V_{-} C L I M \times(E A=1)$

The first estimation seeks to evaluate the way in which the total number of patents influences GDP growth. The second model strives to ascertain the effect of the number of Euro Area (EA) patents on GDP growth, thus, the moderating effect of belonging to the EA on the impact of the number of patents on GDP growth. In turn, the third calculation analyses the impact of the number of environmental patents on GDP growth while the fourth estimate studies how the number of environmental EA patents impacts on GDP growth (the moderating effect of EA membership on the environmental patent impact on GDP growth). Finally, the last two estimations approach the effect of the three environmental patent types on GDP growth and the impact of the three types of environmental patent types on EA member state GDP growth (the moderating effect of EA membership on the three types of environmental patent and their impact on GDP growth).

We processed the data obtained by the STATA software version 12.0 (StataCorp LP, Texas, USA).

\section{RESULTS}

\subsection{Descriptive Statistics}

Table 3 features the descriptive statistics and the correlation coefficients for the respective endogenous variables deployed in the econometric modelling. We would observe that the average GDP growth rate was $1.83 \%$ with populations growing by an average of $0.64 \%$ with the occurrence of an average decrease of $0.82 \%$ in gross fixed capital formation, with the current account balance returning a positive weighting on GDP $(1.65 \%)$ and the median number of hours worked per employee totaling 1,770. In terms of the patents, on average, 305.61 patents were granted for each million inhabitants per country and per year, with 29.49 patents relating to environmental matters, 13.07 for environmental management patents, 1.19 for water-related adaptation technologies patents and 21.63 for climate change mitigation patents. 
Table 3. Correlation matrix for variables used in the empirical analyses

\begin{tabular}{|l|l|l|l|l|l|l|l|l|l|l|l|l|l|}
\hline & & Average & SD & $\mathbf{1}$ & $\mathbf{2}$ & $\mathbf{3}$ & $\mathbf{4}$ & $\mathbf{5}$ & $\mathbf{6}$ & $\mathbf{7}$ & $\mathbf{8}$ & $\mathbf{9}$ & $\mathbf{1 0}$ \\
\hline 1 & GDP_GR & 1.83 & 3.81 & 1 & & & & & & & & & \\
\hline 2 & POP_GR & 0.64 & 0.80 & $0.140^{*}$ & 1 & & & & & & & & \\
\hline 3 & CAB & -0.82 & 6.69 & $0.518^{*}$ & 0.112 & 1 & & & & & & & \\
\hline 4 & GFC & 1.65 & 10.32 & $-0.138^{*}$ & 0.058 & -0.054 & 1 & & & & & & \\
\hline 5 & HOURS & 1.77 & 2.16 & $0.154^{*}$ & -0.007 & 0.066 & $-0.540^{*}$ & 1 & & & & & \\
\hline 6 & PAT & 305.61 & 405.21 & 0.050 & -0.002 & -0.002 & $0.334^{*}$ & 0.074 & 1 & & & & \\
\hline 7 & PAT_ENV & 29.49 & 37.61 & -0.005 & -0.046 & -0.023 & $0.384^{*}$ & -0.068 & $0.730^{*}$ & 1 & & & \\
\hline 8 & PAT_ENV_MAN & 13.07 & 16.93 & 0.028 & -0.067 & -0.005 & $0.381^{*}$ & -0.032 & $0.739^{*}$ & $0.757^{*}$ & 1 & & \\
\hline 9 & PAT_ENV_WAT & 1.19 & 1.49 & 0.044 & $0.125^{*}$ & 0.046 & $0.421^{*}$ & -0.103 & $0.621^{*}$ & $0.610^{*}$ & $0.768^{*}$ & 1 \\
\hline 10 & PAT_ENV_CLIM & 21.63 & 27.41 & -0.024 & -0.042 & -0.034 & $0.389^{*}$ & -0.113 & $0.689^{*}$ & $0.791^{*}$ & $0.718^{*}$ & $0.786^{*}$ & 1 \\
\hline
\end{tabular}

${ }^{*} p<0,05$

\subsection{Modelling}

Table 4 presents the results stemming from the models estimated. The six models return a higher level of predictive power with an R-squared result varying between 0.791 and 0.825 and the Adjusted R-squared returning values of between 0.687 and 0.693 .

In terms of the control variables, we generally observe how the annual growth of gross fixed capital formation and the annual population growth return a statistically significant positive effects on real GDP growth.

In the case of patents, we may report that the totality of patents $(\beta=0.01 ; p=0.003)$ registers a statistically significant effect on real GDP growth in which the higher the level of patents, the higher the rate of real GDP growth. In terms of the overall patents, there is no moderating effect arising out of EA membership on the influence of patent numbers on real GDP growth. As regards the total number of environmental patents, we do not encounter any significant effect of these on real GDP growth nor any moderating effect of EA membership on this effect. As regards the three specific types of environmental patents, we may report that environmental management patents $(\beta=0.04$; $\mathrm{p}=0.011$ ) do return a statistically significant positive effect on real GDP growth. We would also point to the moderating effect of belonging to the EA on the influence the number of environmental management patents $(\beta=0.05 ; \mathrm{p}=0.005)$ had on real GDP growth, thus, in EA member states the impact of the number of environmental management patents on real GDP growth proves greater than in countries that do not belong to the EA.

With these results in terms of the indicators for innovation and alongside those for environmental innovation, we may report that both contribute towards development and regional growth through the positive impact generated in terms of real GDP growth. A specific social, cultural, economic and political ambience is required for such innovation to emerge and taking on systemic characteristics (Cooke et al., 2004). Edquist (1997) defines innovation systems as incorporating complex elements and components that collectively work together to both mutually condition and generate other complexes even with each of the respective functions being well defined. According to Lundvall (1992), an innovation system contains factors and relationships that interact in the production, spread and utilisation of new economic knowledge. This approach served as the impulse for the exploration of regional innovation systems (Cooke et al., 1997; Cooke, 1998). In addition to aspects related to agglomeration and competitiveness, innovation represents one of the most important factors driving economic growth in the knowledge age. Porter and Stern (2001) defend that the very vitality of innovation depends directly on the capacity for national innovation. This capacity above all derives 
International Journal of Social Ecology and Sustainable Development

Volume $8 \cdot$ Issue $3 \cdot$ July-September 2017

Table 4. Econometric models: Regression coefficients (Standard Error)

\begin{tabular}{|c|c|c|c|c|c|c|}
\hline & Model 1 & Model 2 & Model 3 & Model 4 & Model 5 & Model 6 \\
\hline POP_GR & $0.31(0.15)^{*}$ & $0.33(0.18)$ & $0.33(0.15)^{*}$ & $0.32(0.16)^{*}$ & $0.36(0.16)^{*}$ & $0.32(0.16)$ \\
\hline HOURS & $0.97(0.79)$ & $1.76(0.9)$ & $1.39(0.77)$ & $1.65(1.12)$ & $1.02(0.77)$ & $1.43(1.23)$ \\
\hline $\mathrm{CAB}$ & $-0.06(0.03)$ & $-0.03(0.02)$ & $-0.04(0.03)$ & $-0.03(0.03)$ & $-0.05(0.04)$ & $-0.04(0.03)$ \\
\hline GFC & $\begin{array}{c}0.29 \\
(0.04)^{* * *}\end{array}$ & $\begin{array}{c}0.29 \\
(0.01)^{* * *}\end{array}$ & $\begin{array}{c}0.29 \\
(0.04)^{* * *}\end{array}$ & $\begin{array}{c}0.29 \\
(0.04)^{* * * *}\end{array}$ & $\begin{array}{c}0.29 \\
(0.04)^{* * *}\end{array}$ & $\begin{array}{c}0.29 \\
(0.04)^{* * *}\end{array}$ \\
\hline PAT & $\begin{array}{c}0.01 \\
(0.00)^{* *}\end{array}$ & & & & & \\
\hline PAT_ENV & & & $0.01(0.00)$ & & & \\
\hline PAT_ENV_MAN & & & & & $0.04(0.02)^{*}$ & \\
\hline PAT_ENV_WAT & & & & & $-0.03(0.15)$ & \\
\hline PAT_ENV_CLIM & & & & & $-0.02(0.01)$ & \\
\hline PAT_EA & & $0.01(0.00)$ & & & & \\
\hline PAT_ENV $x(E A=1)$ & & & & $0.00(0.01)$ & & \\
\hline $\begin{array}{l}\text { PAT_ENV_MAN x } \\
(\mathrm{EA}=1)\end{array}$ & & & & & & $\begin{array}{c}0.05 \\
(0.02)^{* *}\end{array}$ \\
\hline $\begin{array}{l}\text { PAT_ENV_WAT x } \\
(\mathrm{EA}=1)\end{array}$ & & & & & & $-0.48(0.38)$ \\
\hline $\begin{array}{l}\text { PAT_ENV_CLIM x } \\
(\mathrm{EA}=1)\end{array}$ & & & & & & $-0.01(0.01)$ \\
\hline $\mathrm{N}$ & 280 & 280 & 280 & 280 & 280 & 280 \\
\hline R Squared & 0.825 & 0.793 & 0.813 & 0.792 & 0.806 & 0.791 \\
\hline Adjusted R Squared & 0.691 & 0.687 & 0.689 & 0.687 & 0.693 & 0.691 \\
\hline Wald Chi Squared & $270.45^{* * *}$ & $583.28 * * *$ & $249.76^{* * *}$ & $196.51^{* * *}$ & $356.37 * * *$ & $312.14 * * *$ \\
\hline
\end{tabular}

${ }^{*} p<0.05 ;{ }^{* *} p<0,01 ; p<0,001$

from the potentials displayed by each country, at the political and economic levels, to produce a flow of commercially relevant innovations.

\subsection{Final Considerations}

The histories of locally rooted people, their ways of life, forms of thinking, means of interrelating, their cultural traditions, habits and practices constitute simultaneously the seeds for particular forms of innovation and development and barriers to rootless forms of technological development and innovation potentially hostile to historically acquired sociocultural realities.

Through this research project, we verified how environmental based innovation variables return a positive impact on regional development through their positive impact on real GDP. Our research demonstrated not only how innovation impacts on the launching of new companies but also nurtures environment connected innovation and therefore reflecting a rising concern about the needs of both surrounding ecosystems and the planet in general.

In reference to the theme of regional development, we would highlight how this theme commonly emerges in accordance with substantial amounts of investment capital, with the application of technical and scientific means to productive systems and along with a profound restructuring of the economy. Hence, the infrastructures of such areas require considerable public investments in order to render private capital more productive in the corresponding hope that the expansion of networks 
and systems brings about two important consequences. Entrepreneurship support policies have thus become a rule across various territorial levels and even reaching out to the most remote regions. Over the last decade, the European Union and many other OECD member states have introduced policies that apply entrepreneurship as an essential tool for rural development. Similarly, there is a growing level of demand and interest in founding and developing new businesses and business models with this representing a key input into the development and revitalisation processes of various European territories.

As a limitation to our research, we would identify the lack of broken down data for each country and meaning that the conclusions reached remain only very generalist. Future research should carry out this analysis at the national level and not group the countries in order to verify just what the differences are and what motivations drive them. The study of the intrinsic and extrinsic factors to the emergence of entrepreneurship and innovation holds the key to establishing policies able to foster their growth and development and lead to the much sought after regional development and competitiveness. 


\section{REFERENCES}

Acs, Z., \& Varga, A. (2005). Entrepreneurship, agglomeration and technological change. Small Business Economics, 31, 630-640.

Audretsch, D. B., \& Fritsch, M. (2002). Growth regimes over time and space. Regional Studies, 36(2), 113-124. doi:10.1080/00343400220121909

Banbury, C. M., \& Mitchell, W. (1995). The effect of introducing important incremental innovations on market share and business survival. Strategic Management Journal, 16(S1Suppl. 1), 161-182. doi:10.1002/ smj.4250160922

Barney, J. (1991). Firm resources and sustained competitive advantage. Journal of Management, 17(1), 99-120. doi:10.1177/014920639101700108

Birley, S. (1985). The role of networks of cities and growth in regional urban. Journal of Business Venturing, 1,107-117. doi:10.1016/0883-9026(85)90010-2

Cooke, P. (1998). Origins of the concept. In H.-J. Braczyk, P. Cooke, \& M. Heidenreich (Eds.), Regional Innovation Systems - The Role of Governance in a Globalized World (pp. 2-25). London: UCL Press.

Cooke, P. (2002). Knowledge Economies - Clusters, learning and cooperative advantage. London, New York: Routledge Studies in International Business and the World Economy.

Cooke, P., Heidenreich, M., \& Braczyk, H.-J. (Eds.). (2004). Regional Systems of Innovation. London: Routledge.

Cooke, P., Uranga, M., \& Etxebarria, G. (1997). Regional Innovation Systems: Institutional and Organizational Dimensions. Research Policy, 26(4-5), 475-491. doi:10.1016/S0048-7333(97)00025-5

Doloreux, D., \& Melancon, Y. (2008). On the dynamics of innovation in Quebecs coastal maritime industry. Technovation, 28(4), 231-243. doi:10.1016/j.technovation.2007.10.006

Drazin, R., \& Schoonhoven, C. B. (1996). Community, population, and organization effects on innovation: A multilevel perspective. Academy of Management Journal, 39(5), 1065-1083. doi:10.2307/256992

Drucker, P. (1985). Innovation and Entrepreneurship - Practice and Principals. New York: Harper \& Row.

Edquist, C. (1997). Systems of Innovation Approaches - Their Emergence and Characteristics. In C. Edquist (Ed.), Systems of Innovation: Technologies, Institutions and Organizations (Ch. 1, pp. 1-35). London: Pinter.

Farinha, L., Ferreira, J., \& Gouveia, J. (2014). Innovation and Competitiveness: A HighTech Cluster Approach, The Romanian Review Precision Mechanics. Optics \& Mechatronics, 45, 41-48.

Fernandes, C., \& Ferreira, J. (2013). Knowledge Spillovers: Cooperation between Universities and KIBS. $R$ \& D Management, 43(5), 461-472. doi:10.1111/radm.12024

Ferreira, J., Fayolle, A., Fernandes, C., Raposo, M. (2016). Effects of Schumpeterian and Kirznerian entrepreneurship on economic growth: Panel data evidence, Entrepreneurship \& Regional Development.

GEM. (2014, March 15). Global Entrepreneurship Monitor. Retrieved from http://www.gemconsortium.org/ download/1300624165779/GEM\%20GLOBAL\%20REPORT\%202010rev.pdf

Groot, H. L.F., Nijkamp, P. and Stough, R. R. (2004): Entrepreneurship and Regional Economic Development - A spatial perspective. Massachusetts: Edward Elgar Publishing Limited.

Hu, J., \& Hsu, Y. (2008). The more interactive, the more innovative? A case study of South Korean cellular phone manufacturers. Technovation, 28(1-2), 75-87. doi:10.1016/j.technovation.2007.07.010

Hurley, R., \& Hult, G. T. M. (1998). Innovation, market orientation, and organizational learning: An integration and empirical examination. Journal of Marketing, 62(3), 42-54. doi:10.2307/1251742

Hwang, A. (2004). Integrating technology marketing and management innovation. Research Technology Management, 47(4), 27-31. 
Kaminski, P., de Oliveira, A., \& Lopes, T. M. (2008). Knowledge transfer in product development processes: A case study in small and medium enterprises (SMEs) of the metal mechanic sector from São Paulo,Brazil. Technovation, 28(1-2), 29-36. doi:10.1016/j.technovation.2007.07.001

Kirchoff, B. A., \& Phillips, B. D. (1988). The effect of firm formation and growth on job creation in the United States. Journal of Business Venturing, 11, 133-149.

Koc, T., \& Ceylan, C. (2007). Factors impacting the innovative capacity in large-scale companies. Technovation, 27(3), 105-114. doi:10.1016/j.technovation.2005.10.002

Lafuente, E., Vaillant, Y., \& Serarols, C. (2010). Location decisions of knowledge-based entrepreneurs: Why some Catalan KISAs choose to be rural? Technovation, 30(11-12), 590-600. doi:10.1016/j.technovation.2010.07.004

Lemon, M., \& Sahota, P. (2004). Organizational culture as a knowledge repository for increased innovative capacity. Technovation, 24(6), 483-498. doi:10.1016/S0166-4972(02)00102-5

Lundvall, B. A. (1992). National systems of innovation, Towards a theory of innovation and interactive learning. London: Pinter Publishers.

NCOE. (2001). Embracing Innovation: entrepreneurship and American Economic Growth". In National Commission on Entrepreneurship (White Paper).

Porter, M. and Stern S, (2001). Innovation: Location Matters. MIT Sloan Management Review, 42(4), 28-36.

Roberts, P., \& Amit, R. (2003). The dynamics of innovative activity and competitive advantage: The case of Australian retail banking, 1981 to 1995. Organization Science, 14(2), 107-122. doi:10.1287/orsc.14.2.107.14990

Schumpeter, J. A. (1934). The Theory of economic development. Cambridge, MA: Harvard University Press.

Schumpeter, J. A. (1939). Business Cycles. New York: McGraw - Hill.

Schumpeter, J. A. (1942). Capitalism, Socialism and Democracy. New York: Harper \& Row.

Shane, S., \& Venkataraman, S. (2000). The promise of entrepreneurship as a field of research. Academy of Management Review, 25(1), 217-226.

Souitaris, V. (2002). Technological trajectories as moderators of firm-level determinants of innovation. Research Policy, 31(6), 877-898. doi:10.1016/S0048-7333(01)00154-8

Storey, D. J. (1994). Employment. In D.J. Storey (Ed.), Understanding the Small Business Sector (Ch 6, pp. 160-203). London: Routledge.

Tidd, J., Bessant, J., \& Pavitt, K. (1997). Managing Innovation. Chichester: Wiley.

Tushman, M., \& O'Reilly, C. (1997). Winning through innovation: a practical guide to leading organizational change and renewal. Boston: Harvard Business School Press.

Wernerfelt, B. (1984). A resource -based view of the firm. Strategic Management Journal, 5(2), 171-180. doi:10.1002/smj.4250050207 
Cristina Isabel I. Fernandes (PhD in Management) is Assistant Professor at the Instituto Politécnico de Castelo Branco, Portugal. She is researcher member at NECE- Research Centre in Business Sciences, University of Beira Interior (UBI). Her research interests are: Knowledge Intensive Business Services, Innovation, Competitiveness and Entrepreneurship. She has published several papers in international journals.

Pedro Mota Veiga holds a PhD in Management from the University of Beira Interior (Portugal) and is Assistant Professor at Portucalense University. His current research are focused on Competitiveness, Strategy, Innovation, Entrepreneurship and Quantitative Methods and he has published several articles in international journals about these research domains.

Marta Peris-Ortiz is a PhD in Management. She is an Associate Professor in the Polytechnic University of Valencia. She received her $P h D$ in Management from the University of Valencia. Since 2015, she has been a member of the DEVA agency evaluator group, responsible for evaluating degrees and masters in Andalucia (Spain). She has published several articles in international journals and is editor of various international books. Her current research is focused on the topics of entrepreneurship, innovation, knowledge and sustainable development.

Carlos Rueda-Armengot holds a PhD in Management from the University of Valencia and is Associate Professor at Universitat Politècnica de València. His research interests are focused on Entrepreneurship, Human Resource Management and Organizational Economics. 